\title{
CORRECTION OF RESISTANCE TO PENETRATION BY PEDOFUNCTIONS AND A REFERENCE SOIL WATER CONTENT(1)
}

\author{
Moacir Tuzzin de Moraes ${ }^{(2)}$, Henrique Debiasi ${ }^{(3)}$, J ulio Cezar Franchini ${ }^{(3)}$ \& Vanderlei \\ Rodrigues da Silva ${ }^{(4)}$
}

\begin{abstract}
SUMMARY
The soil penetration resistance is an important indicator of soil compaction and is strongly influenced by soil water content. The objective of this study was to develop mathematical models to normalize soil penetration resistance (SPR), using a reference value of gravimetric soil water content (U). For this purpose, SPR was determined with an impact penetrometer, in an experiment on a Dystroferric Red Latossol (Rhodic E utrudox), at six levels of soil compaction, induced by mechanical chiseling and additional compaction by the traffic of a harvester (four, eight, 10, and 20 passes); in addition to control treatment under no-tillage, without chiseling or additional compaction. To broaden the range of $U$ values, SPR was evaluated in different periods. Undisturbed soil cores were sampled to quantify the soil bulk density (BD). Pedotransfer functions were generated correlating the values of $U$ and BD to the SPR values. By these functions, the SPR was adequately corrected for all $U$ and BD data ranges. The method requires only SPR and $U$ as input variables in the models. However, different pedofunctions are needed according to the soi I layer evaluated. After adjusting the pedotransfer functions, the differences in the soil compaction levels among the treatments, previously masked by variations of $\mathrm{U}$, became detectable.
\end{abstract}

Index terms: pedotransfer functions, Oxisol, impact penetrometer, soil compaction.

(1) Received for publication in February 15, 2012 and approved in September 27, 2012.

(2) Master Student, Pos-Graduation Program of Soil Science, Universidade Federal de Santa Maria - UFSM. Cidade Universitária. Av. Roraima, 1000, Camobi. CEP 97105-300 Santa Maria (RS). E-mail: moacir.tuzzin@gmail.com

(3) Researcher, Embrapa Soja. Rod. Carlos J oão Strass, Distrito de Warta. Caixa Postal 231. CEP 86001-970 Londrina (PR). Email: henrique.debiasi@embrapa.br; julio.franchin@embrapa.br

(4) Professor, Departament of Environment and Agronomy Science, UFSM. Campus de Frederico Westphalen. Linha Sete de Setembro, s/n. Rod. BR 386, km 40. CEP 98400-000 Frederico Westphalen (RS). E-mail: vanderlei@ufsm.br 


\title{
RESUMO: CORREÇÃO DA RESISTÊNCIA À PENETRAÇÃO USANDO UMA UMIDADE DO SOLO DE REFERÊNCIAE PEDOFUNÇÕES
}

\begin{abstract}
A resistência do sol o à penetração (SPR) éum dos principais indi cadores do estado de compactação do sol o; contudo, a SPR éal tamentei nfl uenciada pel o conteúdo deágua no solo. O objetivo destetrabal ho foi desenvolver model os matemáticos para a correção da SPR para um valor deumidadegravimétrica (U) dereferência. Para isso, a SPR foi determinada, por meio de um penetrômetro de impacto, em um experimento instalado sobre um Latossolo Vermel ho distroférrico, usando seis níveis de compactação do solo, obtidos por meio da escarificação mecânica eda compactação adicional, pel o tráfego deuma col hedora degrãos autoprope ida (quatro, oi to, 10 e20 passadas), al ém de uma testemunha, a qual foi mantida sob sistema planti o di reto sem escarificação ou compactação adi cional. A fim deobter ampla variação nos valores de U, as avaliações da SPR foram realizadas em diferentes épocas. Amostras desol o com estrutura preservada foram col etadas para determinar a densidadedo sol o (BD). Foram geradas funções de pedotransferência relacionando os val ores deSPR, deU edeBD. Usando essas funções, a correção da SPR foi satisfatória para todas as amplitudes de U eBD. O método requer apenas SPR eU comovariáveis deentrada dos model os. No entanto, são necessárias diferentes equações, em função da camada desol o avaliada. A aplicação das funções depedotransferência, obtidas nestetrabal ho, permiteobservar diferenças no estado de compactação do sol o entre os tratamentos, que antes não eram detectadas, em função de variações na U.
\end{abstract}

Termos de indexação: função de pedotransferência, Latossolo Vermelho, penetrômetro de impacto, compactação do solo.

\section{INTRODUCTION}

Thesoil compaction level can beassessed based on soil penetration resistance(SPR), which is determined by penetrometry. This method has someadvantages, e.g., the easiness and speed in obtaining data; identification of compacted layers at different depths; and high correlation with plant root growth (Bengough et al., 2011).

Despite the advantages of using penetrometers, SPR varies directly in function of soil bulk density (BD) and inversely in function of soil water content (U) (Busscher, 1990; Bengough et al., 2001; Vaz et al., 2011). This fact limits comparisons of soils of the same type with different water contents, once a small reduction or increasein $U$ results in a largeincrement or reduction of SPR (Vaz et al., 2011), leading to an under- or overestimation of the soil compaction level. Correlation between SPR and soil water content have al ready been exhaustivel y studied; nevertheless SPR depends on factors such as: soil management (Busscher et al., 1997); compaction level (Torres \& Saraiva, 1999; Bengough et al., 2001; To\& Kay, 2005; Almeida et al., 2008); organic matter content (To \& Kay, 2005); and soil texture (Almeida et al., 2008; Vaz et al., 2011).

The most commonly used functions to express correl ations between SPR and gravimetric soil water content $(U)$ werethenegative exponential (Almeida et al., 2008; Silveira et al., 2010) or negative power function (Busscher et al., 1997; Almeida et al., 2008; Silveira et al., 2010; Vaz et al., 2011) equations. Vaz et al. (2002) indicated that the ideal procedure would beto measure U together with SPR, and apply some type of correction or normalization for a referencevalue of soil water content afterwards. This proceduremay reduce interpretation problems of results obtained under different field conditions and soil management systems (Busscher et al., 1997).

One of the earliest attempts to correct the values of SPR to a reference value of soil water content was performed by Busscher (1990), whoadjusted regression equations using SPR, BD and U data. Busscher et al . (1997) devel oped a method to correct SPR as a function of $U$, based on the first term of a Taylor series. These authors, however, adjusted regression equations correlating SPR exclusively with $U$, without considering other variables, such as the soil compaction level. Thus, normalization of SPR to a reference value of $U$, through that method, implies in theuse of different regression equations, in function of the soil management system. According to Almeida et al. (2008), the correction of SPR data needs several equations, based on different conditions of soil textureand BD.

A correction method, based on volumetric soil water content $(\theta)$, associated to the matric potential of $-10 \mathrm{kPa}$, together with the procedure proposed by Busscher et al. (1997), was proposed by Vaz et al. (2011). These authors described the need to measure theBD together with theSPR todeterminethe $\theta$ values as a great disadvantage of the method. I $n$ this sense, Vaz et al. (2011) concluded that U-based models could be a less complex and laborious procedure of SPR correction.

The objective of this study was to develop a method from the procedure proposed by Busscher et al . (1997) 
for a Rhodic Eutrudox, to correct SPR values to a reference value of $U$ through pedotransfer equations that correlate SPR to BD and U.

\section{MATERIAL AND METHODS}

This study was carried out at the Experimental Station of E mbrapa Soybean, in Londrina, State of Paraná, Southern Brazil (lat. $23^{\circ} 11^{\prime}$ S, long. $51^{\circ} 11^{\prime}$ W; $620 \mathrm{~m}$ asl). The experiment was carried out on a Dystroferric Red Latossol (Brazilian soil dassification) (Santos et al., 2006), or Rhodic Eutrudox (American soil classification) (Soil Survey Staff, 2010), under notillage(NT) since 1996, with $731 \mathrm{~g} \mathrm{~kg}^{-1}$ clay, $146 \mathrm{~g} \mathrm{~kg}^{-1}$ silt, $123 \mathrm{~g} \mathrm{~kg}^{-1}$ sand, $18.50 \mathrm{~g} \mathrm{~kg}^{-1}$ organic carbon, and particle density of $2.96 \mathrm{M} \mathrm{g} \mathrm{m}^{-3}$ in the $0-20 \mathrm{~cm}$ layer. The average slope of the experimental area is $0.03 \mathrm{~m} \mathrm{~m}^{-1}$.

To obtain the SPR correction equations as function of $U$, the variation range of the parameters used for their adjustment (SPR, BD, and U) must be wide enough. For this purpose, an experiment was established in rows in August 2010, using a completely randomized design, with two replications. The treatments were arranged in plots $(2.5 \times 20 \mathrm{~m})$, consisting of six soil compaction levels: NT with recent chiseling (NTCh); NT without chiseling and no additional compaction (NT); and NT with additional compaction by harvester traffic at four intensities, induced by four (NTH4), eight (NTH8), 10 (NTH 10), and 20 (NTH20) passes over the same track. The harvester used had a mass of $10.28 \mathrm{Mg}$ and a tire-soil contact pressure of 0,23 $\mathrm{MPa}$ in the front axle. The soil chiseling was performed by using a 5-shank chisel plow, reaching a depth of $0.3 \mathrm{~m}$.

Prior to the earliest SPR assessment and after treatment application, the whol e experiment was irrigated (irrigation level $100 \mathrm{~mm}$ ), in order to uniformize and raise $U$ values to over $32.3 \%$, corresponding to the soil field capacity of the experimental area, determined at a matric potential of $0.01 \mathrm{MPa}$ in a pressure plate apparatus (Embrapa, 1997). The SPR was measured in nine evaluations (two, three, four, seven, nine, 11, 14, 23 , and 31days after irrigation) which, together with the lack of rainfall in the experimental period, widened the variation range of $U$ values. The SPR was determined in the soil layers 5.5-10.5 and 13.5$18.5 \mathrm{~cm}$, with an impact penetrometer (model IAAPIanal sucar-Stolf) (Stolf, 1991), using a $130 \mathrm{~mm}^{2}$ base area and $30^{\circ}$ circular stainless steel cone (Asabe, 2010). The SPR readings were performed at eight points, $15 \mathrm{~cm}$ away from each other, along a line (transect) transversal to the harvester track and chisel plow passes. In each assessment, two replications (transects) were used per compaction level. Next to each transect, two soil samples were collected (layers 5.5-10.5 and 13.5$18.5 \mathrm{~cm}$ ), to determine $U$, according to $E$ mbrapa (1997).

Undisturbed soil samples were collected in stainless steel cores (height $5 \mathrm{~cm}$ x internal diameter $5 \mathrm{~cm}$ ), horizontally inserted by means of a hydraulic jack, in the center of the layers 5.5-10.5 and 13.5$18.5 \mathrm{~cm}$, on the wall of trenches opened in each plot. For each treatment and soil layer, 24 soil cores were sampled, totaling 288 samples. In thelaboratory, these cores wereanalyzed for $\mathrm{BD}$, and $\mathrm{U}$ equivalent to the soil field capacity $(0.01 \mathrm{MPa})$ by means of a pressure plate apparatus (E mbrapa, 1997). The permanent wilting point was determined in disturbed soil samples, according to the method described by Klein et al. (2006), using a thermocouple psychrometer (Decagon, model WP4-T).

The SPR values were adjusted to $U$ values by an equation of the potential typeused by Busscher et al. (1997). To facilitatelater computations, the equation was linearized (E quation 1):

$$
\mathrm{RP}=\mathrm{b}+\mathrm{a} \operatorname{Ln}(\mathrm{U})
$$

where $b$ and $a$, areempirically adjusted parameters of the models; and $\operatorname{Ln}(U)=$ natural logarithm of gravimetric soil water content.

Functions expressing the correlation between SPR and $U$ wereestimated for each treatment (compaction levels) and soil layer. This means that, corresponding to each mean BD of the different treatments and layers, there is a valuefor parameter $a$, which is the angular coefficient of equation 1 (i.e., the first derivative) and therefore represents the variation rate of SPR with LnU. In this sense, the extent of SPR variation in function of $U$ increases with increasing BD (Bengough et al., 2001; To\& Kay, 2005; Almeida et al., 2008). Therefore, the next step of the method, which represents a major advance in relation to the correction procedure proposed by Busscher et al. (1997), was to relate the module of the angular coefficient of the functions that represent the relationship between SPR and LnU (| a| ) with the mean BD measured per treatment, according to equation (2):

$$
|\mathrm{a}|=\mathrm{CBD}^{\mathrm{d}}
$$

wherec and $d$ areempirically adjusted parameters of themodels.

TheSPR was corrected by thefirst term of a Taylor series (Equation 3) (Busscher et al., 1997). TheU value of $27 \%$ was used as reference to correct SPR, corresponding to the center of the friability range, as determined by Torres \& Saraiva (1999) for the same soil type, with a soil management similar tothat used in the experiment of this study.

$$
\mathrm{SPR}_{\text {corr. }}=\mathrm{SPR}_{\text {read }}-\left[|\mathrm{a}|\left(\mathrm{LnU}_{\text {ref. }}-\mathrm{LnU}_{\text {read }}\right)\right]
$$


where $\mathrm{SPR}_{\text {corr. }}=$ soil resistance to penetration corrected in function of the reference value of the gravimetric soil water content $\left(\mathrm{U}_{\text {ref. }}\right)$; $S P R_{\text {read }}=$ soil resistance to penetration read in the field; $\mathrm{LnU}_{\text {ref. }}=$ natural logarithm of $\mathrm{U}_{\text {ref. }}(27 \%)$; $\mathrm{LnU}_{\text {read }}=$ natural logarithm of $U$, of the same site and soil layer as the SPR assessment.

So far, the method proposed to correct the SPR in function of $U$, required $B D$ data to determine $|a|$. However, when SPR is used as indicator of soil compaction in thefield, theassessment of BD is usually infeasible, oncethequantification method is laborious and time-consuming. To eliminate the need of determining $B D$, pedotransfer functions wereadjusted to estimatethis property in function of SPR $\mathrm{R}_{\text {read, }}$ specific for six intervals of $U$ values in the $5.5-10.5 \mathrm{~cm}$ layer and four intervals in $13.5-18.5 \mathrm{~cm}$ (Table 1). The U intervals were determined so as to meet the fol lowing criteria, in both soil layers: i) a minimum number of five points per soil water content interval; ii) in each interval, all treatments should be present for a sufficient variation range of $\mathrm{BD}$ and SPR; and iii) determination coefficient $\left(r^{2}\right)$ of pedofunctions $>0.70$.

Tovalidatetheproposed method, the pedotransfer functions were applied to SPR data measured in another experiment by Torres \& Saraiva (1999), in the layers 5.5-10.5 and $13.5-18.5 \mathrm{~cm}$ of a very clayey Rhodic Eutrudox under no-tillage at four soil compaction levels evaluated over time, totaling $13 \mathrm{U}$ values. It is worth remembering that this data set was not used for the pedofunctions adjustment, but only tovalidatethemethod. For this purpose, theSPR data at $U$ of $27 \%$, determined at different soil compaction levels using equations relating SPR toU

Table 1. E quations to estimate the soil bulk density (BD) using the soil resistance to penetration (SPR ) as independent variable, for different soil layers and intervals of gravimetric soil water content (U), on a R hodic E utrudox

\begin{tabular}{|c|c|c|}
\hline Interval of U (\%) & Equation ${ }^{(1)}$ & No. of equation \\
\hline \multicolumn{3}{|c|}{$5.5-10.5 \mathrm{~cm}$} \\
\hline If, $21.1<U \leq 23.1$ & $B D=e P^{f}$ & 4 \\
\hline If, $23,1<U \leq 25.1$ & $B D=g+h R P$ & 5 \\
\hline If, $25.1<U \leq 27.1$ & $B D=i+j R P$ & 6 \\
\hline If, $27.1<U \leq 29.1$ & $\mathrm{BD}=\mathrm{k} \mathrm{RP}^{\mathrm{I}}$ & 7 \\
\hline If, $29.1<U \leq 31.5$ & $\mathrm{BD}=\mathrm{m} \mathrm{RP}^{\mathrm{n}}$ & 8 \\
\hline If, $31.5<U \leq 34.5$ & $B D=o P^{p}$ & 9 \\
\hline \multicolumn{3}{|c|}{$13.5-18.5 \mathrm{~cm}$} \\
\hline If, $23.1<U \leq 26.3$ & $B D=q R P^{r}$ & 10 \\
\hline If, $26.3<U \leq 29.1$ & $B D=s P^{t}$ & 11 \\
\hline If, $29.1<U \leq 32.1$ & $B D=u R P v$ & 12 \\
\hline If, $32.1<U \leq 35.1$ & $B D=x P^{z}$ & 13 \\
\hline
\end{tabular}

(1) e, f, g, h, i, j, k, l, m, n, o, p, q, r, s, t, u, v, x, and $z$ are empiric parameters to adjust the models. adjusted with the data obtained by Torres $\&$ Saraiva (1999), were compared to SPR data corrected for the sameU value, by the method proposed here, by means of linear regression analysis.

Results were subjected to ANOVA and treatment means compared by the Tukey test, at $5 \%$ probability, using the Statistical Analysis System (SAS, 2002). The same software was used for regression analysis to adjust the pedotransfer functions.

\section{RESULTS AND DISCUSSION}

In both soil layers, BD was significantly higher in the treatments with additional soil compaction after harvester trafficthan in theNT (Table2). I contrast, soil tilling by chiseling resulted in lower BD than in the other treatments. In the 5.5-10.5 cm layer, BD varied from $1.10 \mathrm{Mg} \mathrm{m}^{-3}$ (NTCh) to $1.50 \mathrm{Mg} \mathrm{m}^{-3}$ (NTH20), which is near the maximum BD estimated by the Normal Proctor Test for this Oxisol, corresponding to $1.53 \mathrm{Mg} \mathrm{m}^{-3}$ (Torres \& Saraiva, 1999). Similarly, in thelayer $13.5-18.5 \mathrm{~cm}$, BD varied from $1.10 \mathrm{Mg} \mathrm{m}^{-3}$ (NTCh) to $1.42 \mathrm{Mg} \mathrm{m}^{-3}$ (NTH20). Ther efore, the BD variation range was large in both soil layers, which is a basi crequirement for adequate pedofunction adjustments to correct SPR to a reference $U$ value.

In the 5.5-10.5 cm layer of treatment NTH20, the introduction of thepenetrometer into the soil led to the formation of vertical cracks bel ow the cone, resulting in low SPR values (data not presented), incoherent with the high BD measured in this layer and treatment (Table 2). At high BD and low U values, To \& Kay (2005) al so observed that the penetrometer movement in the soil forms small vertical craks right bel ow the cone, reducing theSPR values. Therefore, theSPR data obtained in NTH20, layer $5.5-10.5 \mathrm{~cm}$, were not considered for the establishment of the pedotransfer functions. This problem was not observed in the 13.5$18.5 \mathrm{~cm}$ layer, possibly as a consequence of lower BD than in the 5.5-10.5 cm layer. Thus, results obtained in treatment NTH20, layer $13.5-18.5 \mathrm{~cm}$, were used in the adjustment of pedotransfer functions.

The assessments of SPR in different periods resulted in a wide variation range of $U$, which is also a requirement for the adjustment of pedotransfer functions. Values of $U$ varied between 34.1 and 21.1 $\%(5.5-10.5 \mathrm{~cm})$, and between 34.8 and $23.6 \%$ (13.5$18.5 \mathrm{~cm}$ ). Within these variation ranges, minimum and maximum values were similar to the $U$ values associated with the permanent wilting point (1.5 MPa) and the field capacity ( $0.01 \mathrm{MPa})$, corresponding, in the mean among treatments, to 24.8 and $32.3 \%$, respectively. The large variation amplitude for $\mathrm{BD}$ and $U$ (Table 2 ) resulted in a widerange of SPR values $(0.57-21.66 \mathrm{MPa}$ in the $5.5-10.5 \mathrm{~cm}$, and $0.74-$ 14.31 MPa in the 13.5-18.5 cm). 
Table 2. Descriptivestatistics for the soil bulk density of a R hodic E utrudox, assessed at different compaction levels and in two soil layers

\begin{tabular}{|c|c|c|c|c|c|c|c|c|}
\hline Treatment & No. & Minimum & Mean & Maximum & Median & Modal & Standard deviation & CV (\%) \\
\hline \multicolumn{9}{|c|}{$5.5-10.5 \mathrm{~cm}$} \\
\hline $\mathrm{NTCh}^{(1)}$ & 24 & 0.95 & $1.10 \mathrm{Ea}^{* *}$ & 1.28 & 1.11 & 1.04 & 0.073 & 6.67 \\
\hline NT & 24 & 1.16 & $1.25 \mathrm{Da}$ & 1.32 & 1.25 & 1.25 & 0.044 & 3.50 \\
\hline NTH4 & 24 & 1.28 & $1.36 \mathrm{Ca}$ & 1.46 & 1.36 & 1.36 & 0.038 & 2.84 \\
\hline NTH8 & 23 & 1.38 & $1.43 \mathrm{Ba}$ & 1.47 & 1.44 & 1.47 & 0.030 & 2.11 \\
\hline NTH1O & 24 & 1.36 & $1.45 \mathrm{Ba}$ & 1.52 & 1.46 & 1.46 & 0.040 & 2.86 \\
\hline NTH2O & 23 & 1.43 & $1.50 \mathrm{Aa}$ & 1.53 & 1.50 & 1.52 & 0.030 & 2.01 \\
\hline \multicolumn{9}{|c|}{$13.5-18.5 \mathrm{~cm}$} \\
\hline NTCh & 24 & 0.98 & 1.10 Da & 1.23 & 1.11 & 1.15 & 0.069 & 6.32 \\
\hline NT & 24 & 1.16 & $1.25 \mathrm{Ca}$ & 1.32 & 1.26 & 1.27 & 0.043 & 3.42 \\
\hline NTH4 & 24 & 1.28 & $1.34 \mathrm{Bb}$ & 1.43 & 1.33 & 1.33 & 0.036 & 2.69 \\
\hline NTH8 & 24 & 1.29 & $1.36 \mathrm{Bb}$ & 1.42 & 1.36 & 1.35 & 0.026 & 1.93 \\
\hline NTH1O & 24 & 1.26 & $1.38 \mathrm{Bb}$ & 1.47 & 1.38 & 1.44 & 0.580 & 4.18 \\
\hline NTH2O & 24 & 1.34 & $1.42 \mathrm{Ab}$ & 1.49 & 1.42 & 1.43 & 0.048 & 3.42 \\
\hline
\end{tabular}

(1) No-tillage with soil chiseling (NTCh), No-tillage without chiseling or additional compaction (NT), NT with additional compaction by 4 (NTH4), 8 (NTH8), 10 (NTH10) and 20 (NTH20) harvester passes. **Treatments followed by the same upper case letter in the same soil layer, or lower case letter in soil layers of the same treatment, do not differ from each other statistically by the Tukey test at $5 \%$.

The correlation between SPR and U was expressed satisfactorily by equation (1), since the adjustment was statistically significant $(p<0.01)$ and $r^{2}$ values were $>0.90$, for all treatments and soil layers (Figure 1 ). When $U$ increased, the SPR differences among treatments decreased (Figure 1), in agreement with results of Torres \& Saraiva (1999). The differences among treatments for SPR practically disappeared when U approached field capacity (32.3\%; L nU 3.47) (F igure 1). Thus, determining SPR at field capacity, as recommended by the standard ASABE EP542 (ASABE , 2006), is inappropriate when theobjective is to use the SPR as an indicator of the effects of traffic and soil management on the compaction level.

The parameter $|a|$ of the regression equations relating SPR to LnU increased with the increasing compaction level in each treatment (Figure 1), i.e., the higher the compaction level, thehigher theincrease in SPR with decreasein $U$, as al ready described by Torres \& Saraiva (1999) and Bengough et al . (2001). From this observation, a power function was fit expressing the variation of |a| with the mean BD of each treatment (Figure 2). The use of this equation all owed estimating $|\mathrm{a}|$ at different BD values, which werethen used in equation (3). Thevalues of | al werehigher in the 13.5-18.5 cmthan the 5.5-10.5 cmlayer for theentire $B D$ variation range (Figure 1 ), indicating that SPR is moresensitivetoU variation in deeper soil layers. This result also shows that the correction of SPR to a reference $U$ value, through this method, requires specific pedotransfer functions for each soil layer.

The correction of SPR by equation (3) and using $\mid$ a , estimated for each treatment using theBD values obtained in the field, was efficient for the soil layers 5.5-10.5 cm (Figure 3a,b,c,d,e) and 13.5-18.5 cm (Figure $3 f, g, h, i, j, I)$. In all cases, the relationship between $S P R_{\text {read }}$ and $U$ was a negative exponent power function. After correction, SPR $R_{\text {corr }}$ did not vary in function of $U$ $(p>0.05)$. Likewise, the relationship between $S P R_{\text {corr }}$ and $U$ gaveriseto a horizontal straight line, parallel to the abscissa axis, which crosses the SPR $\mathrm{R}_{\text {read }}$ approximately at the reference value of $U\left(U_{\text {ref }}\right)$, equivalent to $27 \%$. Thus, within the entire variation interval of $U$, the SPR corr value was similar to the $S P R_{\text {read }}$ value, obtained in the field, at $27 \%$ of $U$.

To eliminate the need for determining BD in the field to estimate | al, which would limit theextensive use of the method proposed here, pedotransfer functions were adjusted to estimate BD in relation to $S P R_{\text {read. }}$. These functions were specific for six $U$ intervals in the 5.5-10.5 cm layer (Figure 4a), and for four $U$ intervals in the $13.5-18.5 \mathrm{~cm}$ layer (F igure 4b). The model relating SPR to BD and $\theta$, proposed by Busscher (1990), was not used, oncethe BD could not be reliably estimated at extreme SPR and $U$ values. The use of $U$ instead of $\theta$ most likely reduced the model precision in situations of high variations in SPR and U.

In both soil layers and for most $U$ intervals, the relationship SPR $\times$ BD was better expressed by exponential-type models (Figure 4), agreeing with results obtained by Busscher (1990). Nevertheless, in the 5.5-10.5 cm layer and for $U$ ranges between 23.1 and $25.1 \%$ as well as between 25.1 and $27.1 \%$, the best fitting was obtained by the linear model (Figure 4a). Excepting theU interval between 32.1 and $35.1 \%$ 
(plastic soil consistency) in the $13.5-18.5 \mathrm{~cm}$ layer (Figure 4b), the ${ }^{2}$ values of the other fitted functions were $>0.93$ (Figure 4), indicating a high precision in estimating BD, using SPR as independent variable.

Independently of the soil layer, the SPR $\mathrm{R}_{\text {corr }}$ values using the BD estimated by the pedotransfer functions (Figure 4) were similar to those obtained using the BD observed at each soil compaction level (Figure 3). The relationship between $L n U$ and SPR $R_{\text {corr }}$ using $|\mathrm{a}|$, determined from the estimated BD (Figure 3), was also represented by a straight line, parallel to the abscissas axis, cutting the SPR read $x \mathrm{LnU}$ approximately at the values of $U_{\text {ref }}(27 \%)$; demonstrating that the method was efficient in eliminating the effect of $U$ on SPR. In this way, the correction of SPR by $U$ can be performed without determining BD in the field.

Tovalidate the proposed method, the pedotransfer functions were applied to SPR data obtained at different soil compaction levels and $U$ values by Torres \& Saraiva (1999), in previous research of the same soil type and layers used in this study (Figure 5). In all situations, SPR was corrected for the values of $U_{\text {ref }}(27 \%)$, where | a| was determined by means of BD predicted using SPR $\mathrm{R}_{\text {read }}$ as independent variable in the pedotransfer functions (Figure4).

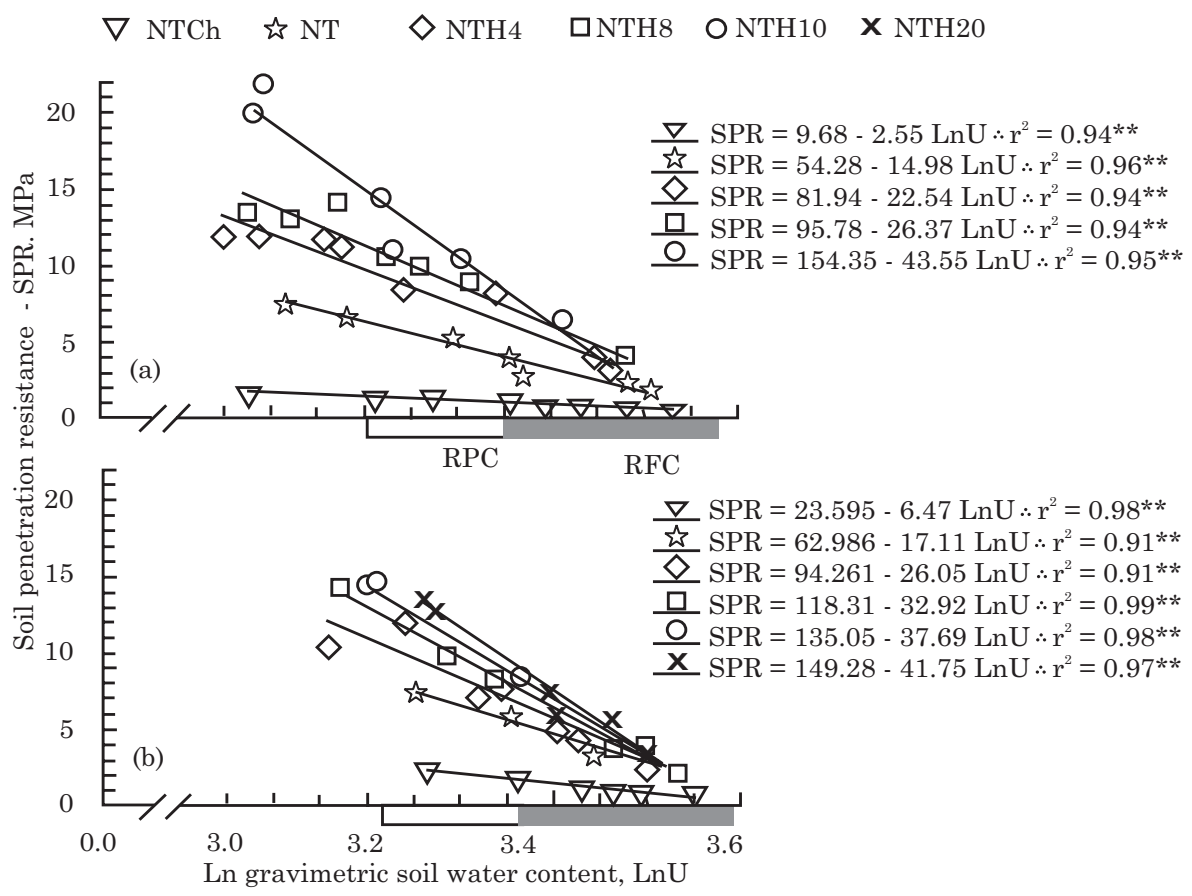

Figure 1. Variation of soil penetration resistance with gravimetric soil water content at each soil compaction level (NTCh =no-tillage with chiseling; NT = no-tillage without chiseling or additional compaction; NTH4, NTH8, NTH10 and NTH20 = NT with additional compaction by four, eight, 10, and 20 harvester passes, respectively), in the layer $5.5-10.5 \mathrm{~cm}$ (a) and $13.5-18.5 \mathrm{~cm}$ (b), in a Rhodic E utrudox. **Statistically significant equations ( $\mathrm{F}$ test, $\mathrm{p}<0.01$ ). RPC $=$ range of plastic consistency; RFC = range of friable consistency of soil.

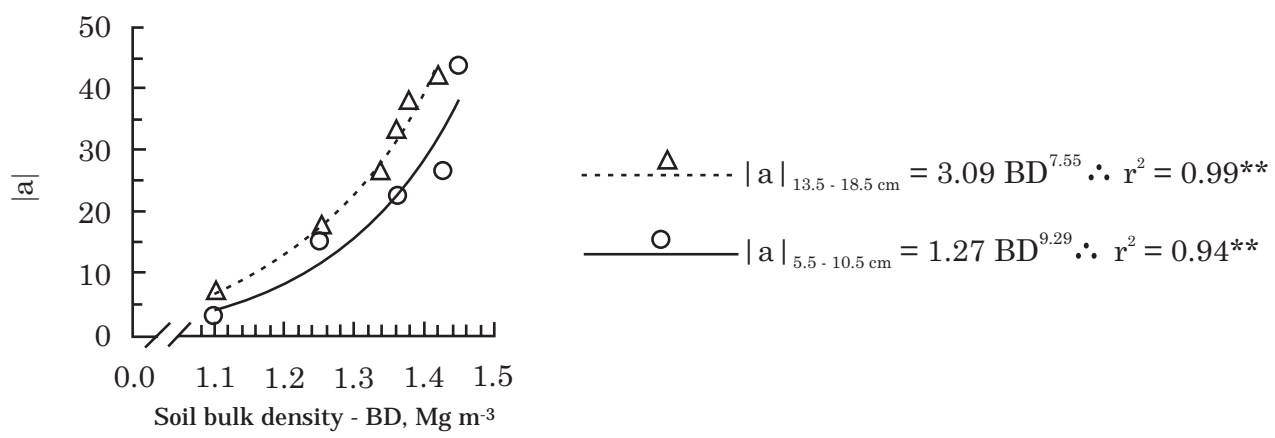

Figure 2. Variation of $\mid$ a| with the soil bulk density assessed in the field in the 5.5-10.5 and 13.5-18.5 cm layer, in a Rhodic E utrudox. ${ }^{* *}$ Statistically significant equations ( $F$ test, $p<0.01$ ). 

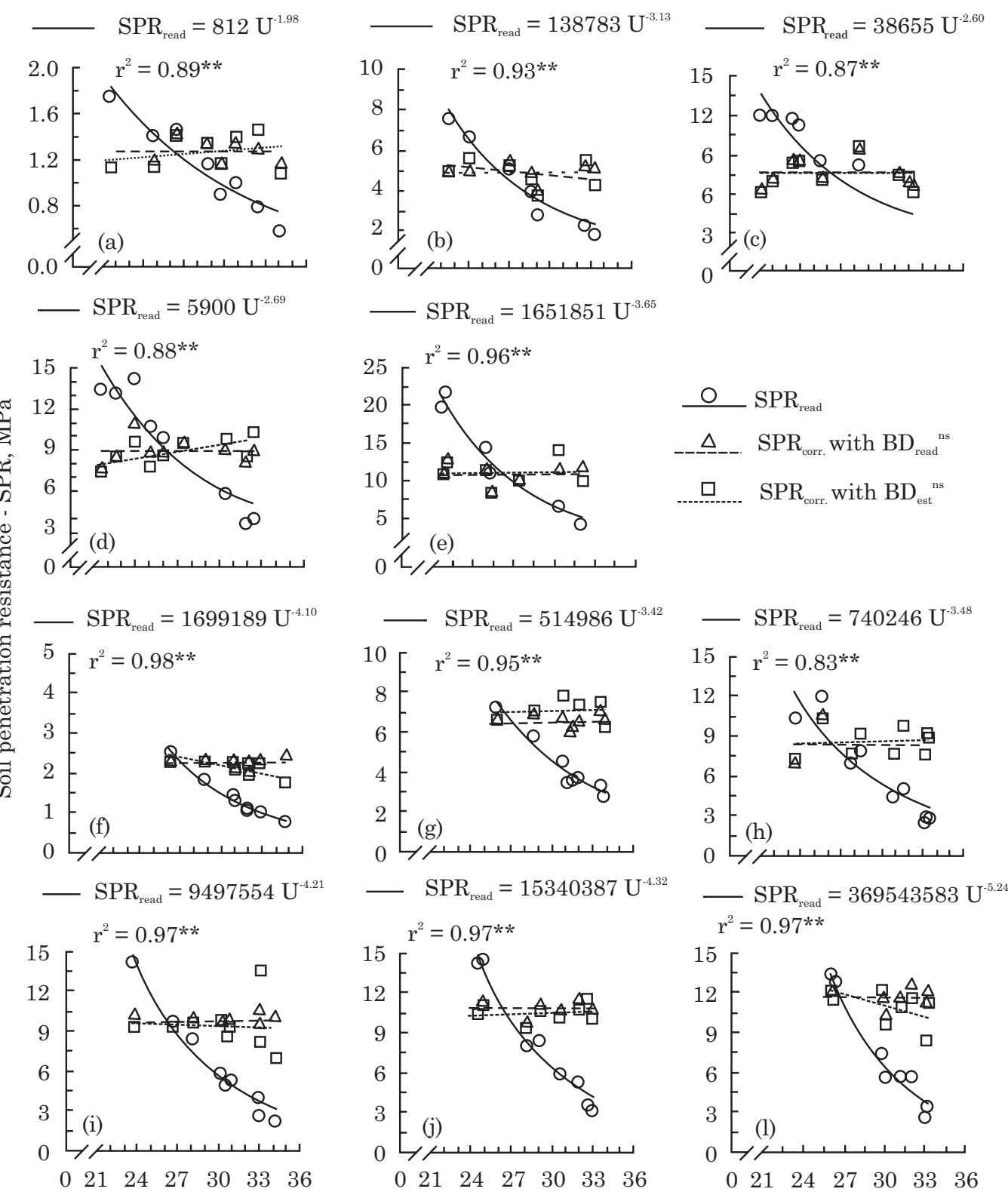

Gravimetric soil water content - U, \%

Figure 3. Correction of soil penetration resistance, in function of gravimetric soil water content in a Rhodic Eutrudox, in the 5.5-10.5 cm layer: a) NTCh =no-tillage with chiseling; b) NT = no-tillage without chiseling or additional compaction; c) NTH4 = NT with additional compaction by four harvester passes; d) NTH8 = NT with additional compaction by eight harvester passes; e) NTH10 $=$ NT with additional compaction by 10 harvester passes; and in the 13.5-18.5 cm layer: f) NTCh; g) NT; h) NTH 4; i) NTH8; j) NTH10; I) NTH20 = NT with additional compaction by 20 harvester passes. ${ }^{* *}$ Significant equations (F test, $p<0.01$ ); ns non-significant. SPR $\mathbf{R}_{\text {corr }}$ with $\mathrm{BD}_{\mathrm{obs}}=\mathrm{SPR}$ corrected in function of $\mathrm{U}$ by using the soil bulk density observed in the field; $S P R_{\text {corr }}$ with $B_{\text {est }}=S P R$ corrected in function of $U$ based on soil bulk density estimated by the pedotransfer functions shown in figure 4.

Prior to correction, the $S P R_{\text {read }}$ in the $5.5-10.5 \mathrm{~cm}$ and 13.5-18.5 cm layer decreased with theincrease of $U$, following a negative-exponent power function (Figure 5). However, variation of SPR $\mathrm{R}_{\text {corr }}$ with $U$ was not statistically significant in both soil layers, resulting in a straight line, approximately parallel totheabscissa axis. The dispersion of someSPR $\mathrm{R}_{\text {corr }}$ values, observed along the straight line of the regression $\mathrm{SPR}_{\text {corr }} \times \mathrm{U}$, mainly in the 5.5-10.5 cm layer (Figure 5a,b,c,d), may be explained by variations in the soil compaction level at each point whereSPR was measured. The existence of this dispersion is important, showing that the 


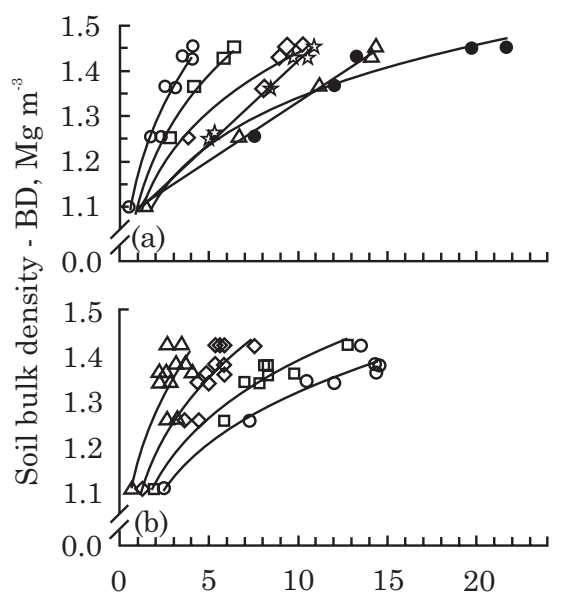

$$
\begin{aligned}
& \text { - } 21.1<\mathrm{U} \leq 23.1 \therefore \mathrm{BD}=1.02 \mathrm{SPR}^{0.1190} \therefore \mathrm{r}^{2}=0.94^{* *} \\
& \triangle 23.1<\mathrm{U}<25.1 \therefore \mathrm{BD}=1.068+0.26 \mathrm{SPR} \therefore \mathrm{r}^{2}=0.99^{* *} \\
& \text { † } 25.1<\mathrm{U} \leq 27.1 \therefore \mathrm{BD}=1.055+0.0366 \mathrm{SPR} \therefore \mathrm{r}^{2}=0.99^{* *} \\
& \diamond 27.1<\mathrm{U} \leq 29.1 \therefore \mathrm{BD}=1.065 \mathrm{SPR}^{0.1303} \quad \therefore \mathrm{r}^{2}=0.97^{* *} \\
& \text { 므 } 29.1<\mathrm{U} \leq 31.1 \therefore \mathrm{BD}=1.1027 \mathrm{SPR}^{0.1452} \therefore \mathrm{r}^{2}=0.99^{* *} \\
& \text { 을 } 31.5<\mathrm{U} \leq 34.5 \therefore \mathrm{BD}=1.154 \mathrm{SPR}^{0.1514} \therefore \mathrm{r}^{2}=0.94^{* *}
\end{aligned}
$$

으 $23.1<\mathrm{U} \leq 26.1 \therefore \mathrm{BD}=0.9764 \mathrm{SPR}^{0.1311} \therefore \mathrm{r}^{2}=0.95^{* *}$

므 $26.3<\mathrm{U} \leq 29.1 \therefore \mathrm{BD}=1.0149 \mathrm{SPR}^{0.1360} \therefore \mathrm{r}^{2}=0.95^{* *}$

$\diamond 29.1<\mathrm{U} \leq 32.1 \therefore \mathrm{BD}=1.0644 \mathrm{SPR}^{0.1479} \therefore \mathrm{r}^{2}=0.93^{* *}$

$\triangle 32.1<\mathrm{U} \leq 35.1 \therefore \mathrm{BD}=1.1512 \mathrm{SPR}^{0.1427} \therefore \mathrm{r}^{2}=0.73 * *$

Soil penetration resistance - SPR, $\mathrm{MPa}$

Figure 4. Pedotransfer functions to estimate soil bulk density in function of soil penetration resistance, for different ranges of gravimetric soil water content in the 5.5-10.5 cm layer (a) and 13.5-18.5 cm layer (b), in a Rhodic E utrudox soil. **Statistically significant equations (F test, p<0.01).

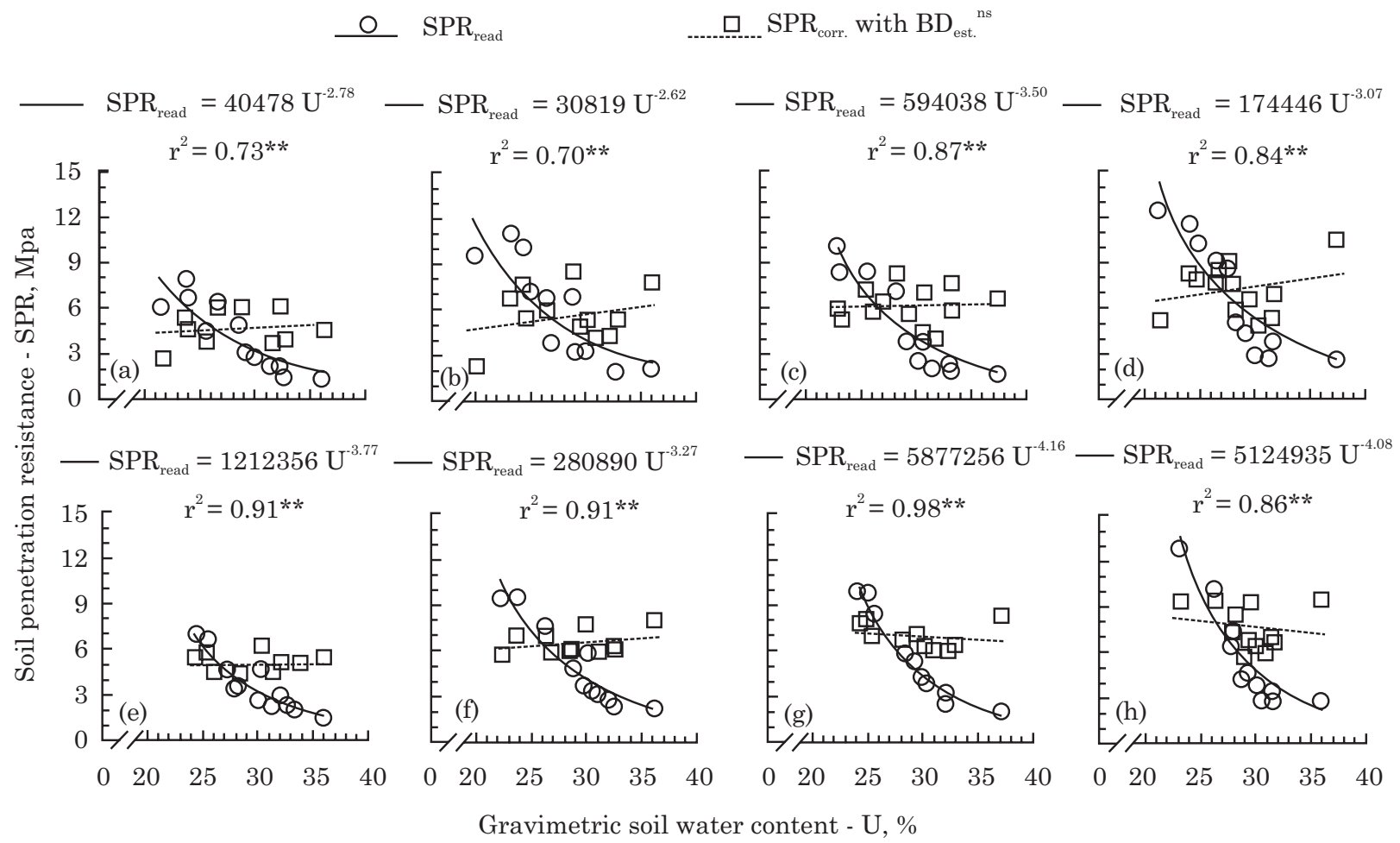

Figure 5. Variation of soil penetration resistance read in the field (SPR $\mathbf{r e a d}_{\text {rea }}$ ) and corrected $\left(\mathbf{S P R}_{\text {corr }}\right)$ with the gravimetric soil water content, in a Rhodic Eutrudox at different compaction levels, in the $5.5-10.5 \mathrm{~cm}$ layer: a) $1.13 \mathrm{Mg} \mathrm{m}^{-3}$; b) $1.30 \mathrm{Mg} \mathrm{m}^{-3}$; c) $1.30 \mathrm{Mg} \mathrm{m}^{-3}$; d) $1.33 \mathrm{Mg} \mathrm{m}^{-3}$; and in the 13.5-18.5 $\mathrm{cm}^{-3}$ layer: e) $1.22 \mathrm{Mg} \mathrm{m}^{-3}$; f) $1.28 \mathrm{Mg} \mathrm{m}^{-3}$; g) $1.29 \mathrm{Mg} \mathrm{m}^{-3}$; h) $1.31 \mathrm{Mg} \mathrm{m}^{-3}$. Original data obtained by Torres \& Saraiva (1999). **Statistically si gnificant equations (F test, $\mathrm{p}<0.01$ ); ns non-significant.

method proposed here minimizes the effect of $U$ on SPR, but without changing the sensitivity of that variable to the soil compaction level.

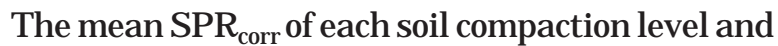
layer was linearly related with the SPR at U of $27 \%$, estimated by the equations fitted to the data measured in the field by Torres \& Saraiva (1999) (Figure 6). In both soil layers $(5.5-10.5$ and $13.5-18.5 \mathrm{~cm})$, the determination coefficient of the linear equations representing the relationship between $\mathrm{SPR}_{\text {corr }}$ and 


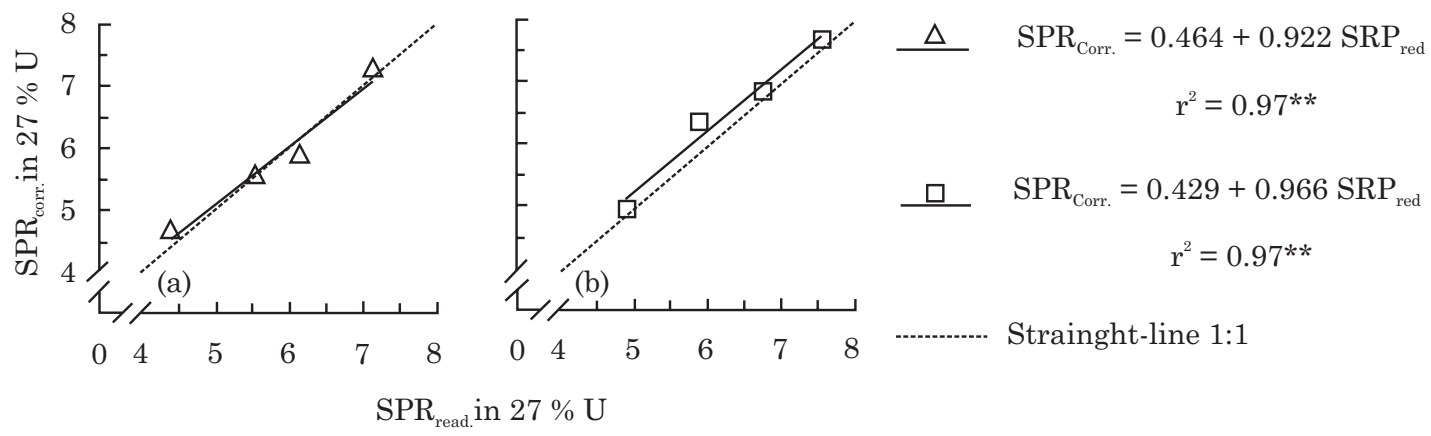

Figure 6. Relationship between the corrected value of soil penetration resistance (SPR corr $_{\text {) and soil }}$ penetration resistance observed at the gravimetric soil water content (U) of $27 \%\left(S P R_{\text {read }}\right.$ ), for the soil layers 5.5-10.5 cm (a), and 13.5-18.5 cm (b), of a Rhodic E utrudox. Original data obtained by Torres \& Saraiva (1999). **Statistically significant equations ( $\mathrm{F}$ test, $\mathrm{p}<0.01$ ).

SPR observed at $27 \%$ of $U$ was high (0.97), very close to the 1:1 line. These results proved that the method of correction, exempting from field determination of $B D$, was efficient in minimizing the effect of $U$ variation on the SPR values when applied to a data set which, although obtained for the same soil type and layer, differs from the data used to fit the pedotransfer functions.

The purpose of correcting SPR data is to diminish the effect of $U$ on theinterpretation of results. Vaz et al. (2002) stated that, despitetheSPR readings taken between field capacity and permanent wilting point, some type of correction is necessary. According to these authors, the variation of $U$ within this range causes a largevariation in SPR, in the order of $5 \mathrm{MPa}$. This variation is sufficient to cause significant distortions in diagnoses of the soil compaction level based on SPR data.

In this study, the SPR $\mathrm{R}_{\text {read }}$ in the $5.5-10.5 \mathrm{~cm}$ layer varied from 2 to $8 \mathrm{MPa}$ for the NT (BD=1.25 $\mathrm{Mg} \mathrm{m}^{-3}$ ) (Figure $3 \mathrm{~b}$ ), and from 4 to $22 \mathrm{MPa}$ for the NTH 10 $\left(B D=1.42 \mathrm{Mg} \mathrm{m}^{-3}\right)$ (Figure 3e). Thus there was an overlapping between theSPR values obtained for the treatments NT and NTH 10, in a way that variations in $U$ may lead toa misinterpretation of results, as for example, that SPR in the NT is equal or higher than in the NTH 10 treatment. After the correction, the SPR values varied from 4 to $5.5 \mathrm{MPa}$ in NT and from 9 to $13 \mathrm{MPa}$ in NTH10. A similar behavior was observed in the 13.5-18.5 cm layer, where $S R_{\text {read }}$ varied from 2.5 to $7.5 \mathrm{MPa}$ in the NT (Figure $3 \mathrm{~g}$ ), and from 3.2 to $11.5 \mathrm{MPa}$ in the NTH 10 treatment (Figure 3j). Theoverlapping of SPR values in the 13.5$18.5 \mathrm{~cm}$ was higher than in the 5.5-10.5 cm layer, increasing the probability of erroneous interpretations, dueto eventual variations of $U$ between treatments. However, after correction, the SPR varied between 6.1 to $7.1 \mathrm{MPa}$ in the treatment NT and from 9.5 to 11.5 MPa in the treatment NTH 10, thus eliminating overlapping of the variation ranges and minimizing therisk of inadequate interpretations. I is important to emphasize that the variations in SPR $\mathrm{R}_{\text {corr }}$, within the sametreatment and soil layer, occur mainly due to spatial variability of soil compaction levels, once the correction was based on the mean BD for each treatment.

In relation to other methods of correcting SPR by the soil water content, the procedure proposed here has some important advantages. For example, the proposed method can be used at different soil compaction levels dueto the adjustment of regression equations to estimate $\mid \mathrm{a}$, , using BD as independent variable, which was not considered in the original method of Busscher et al. (1997). Additionally, theuse of pedotransfer functions to estimate BD from the $S P R_{\text {read }}$ allows a satisfactory correction of SPR to a reference $U$ valuewithout theneed of quantifying $B D$ in the field, which would hamper the use of this method. This represents an important advantage over the method of SPR correction based on the $\theta$ value at a matric potential of $-0,01 \mathrm{MPa}$, as proposed by $\mathrm{Vaz}$ et al. (2011), which requires the field estimation of $B D$. In this context, the use of $U$ instead of $\theta$ is another characteristic of the method proposed here, which allows the correction of SPR without the need to determineBD.

Still, it is important to consider that the pedotransfer functions, which represent the relationship between SPR and BD in different $U$ ranges; SPR and $U$; and $|a|$ and $B D$, are specific for the layers and the soil conditions inherent to this experiment. In other situations, the fitting coefficients or even the models are expected to be different. Ther efore, these adjustments are a condition for the application of this method to soils and layers different from those used in this study.

\section{CONCLUSIONS}

1. The proposed method allows correcting SPR toa reference value of $U$, without affecting the sensitivity of theindicator to the soil compaction level. 
2. With the correction of SPR to a reference value of $U$, differences among treatments, previously masked by variations of $U$, became detectable.

\section{LITERATURE CITED}

ALMEIDA, C.X.; CENTURION, J.F.; FREDDI, O.S.; FALQUETO J ORGE, R. \& BARBOSA, J .C. Funções de pedotransferência para a curva de resistência do solo à penetração. R. Bras. Ci. Solo, 32:2235-2243, 2008.

AMERICAN SOCIETY OF AGRICULTURAL AND BIOLOGICAL ENGINEERS - ASABE. Procedures for using and reporting data obtained with the soil cone penetrometer. ASABE Standard EP542. St. J oseph, 2006.

AMERICAN SOCIETY OF AGRICULTURAL AND BIOLOGICAL ENGINEERS - ASABE. Soil cone penetrometer. ASABE Standard S313.3. St J oseph, 2010.

BENGOUGH, A.G.; CAMPBELL, D.J . \& O'SULLIVAN, M.F. Penetrometer techniques in relation to soil compaction and root growth. In: SMITH, K.A. \& MULLINS, C.E., eds. Soil and environmental analysis. 2.ed. New York, Marcel Dekker, 2001. p.377-403.

BENGOUGH, A.G.; MCKENZIE, B.M.; HALLET, P.D. \& VALENTINE, T.A. Root elongation, water stress, and mechanical impedance: A review of limiting stresses and beneficial root tip traits. J . Exp. Bot., 62:59-68, 2011.

BUSSCHER, W.J . Adjustment of flat-tipped penetrometer resistance data to a common water content. Trans. Am. Soc. Agric. Eng., 3:519-524, 1990.

BUSSCHER, W.J .; BAUER, P.J .; CAMP, C.R. \& SOJ KA, R.E. Correction of cone index for soil water content differences in a coastal plain soil. Soil Tillage Res., 43:205-217, 1997.

EMPRESA BRASILEIRA DE PESQUISA AGROPECUÁRIA EMBRAPA. Manual de métodos de análise de solo. Rio de J aneiro, 1997. 212p.
KLEIN, V.A.; REICHERT, J.M. \& REINERT, D.J . Água disponível em um Latossolo Vermelho argiloso e murcha fisiológica de culturas. R. Bras. Eng. Agríc. Amb., 10:646650, 2006.

SAS LEARNING EDITION. Getting started with the SAS Learning Edition. Cary, 2002. 200p.

SILVEIRA, D.C.; MELO FILHO, J .F.; SACRAMENTO, J .A.A.S. \& SILVEIRA, E.C.P. Relação umidade versus resistência à penetração para um Argissolo Amarelo distrocoeso no recôncavo da Bahia. R. Bras. Ci. Solo, 34:659-667, 2010.

SANTOS, H.G.; J ACOMINE, P.K.T.; ANJ OS, L.H.C.; OLIVEIRA,V.A.; OLIVEIRA, J.B.; COELHO, M.R.; LUMBRERAS, J.F. \& CUNHA, T.J.F., eds. Sistema brasileiro de classificação de solos. 2.ed. Rio de J aneiro, Embrapa Solos, 2006. 306p.

SOIL SURVEY STAFF. Keys to soil taxonomy. 11.ed. Washington, DC, USDA/NRCS, 2010. 338p.

STOLF, R. Teoria e teste experimental de fórmulas de transformação dos dados de penetrômetro de impacto em resistência do solo. R. Bras. Ci. Solo, 15:229-235, 1991.

TO, J . \& KAY, B.D. Variation in penetrometer resistance with soil properties: The contribution of effective stress and implications for pedotransfer functions. Geoderma, 126:261-276, 2005.

TORRES, E. \& SARAIVA, O.F. Camadas de impedimento mecânico do solo em sistemas agrícolas com a soja. Londrina, Embrapa Soja, 1999. 58p. (Circular Técnica, 23).

VAZ, C.M.P.; PRIMAVESI, O.; PATRIZZI, V.C. \& IOSSI, M.F. Influência da umidade na resistência do solo medida com penetrômetro de impacto. São Carlos, Embrapa Instrumentação Agropecuária, 2002. 5p. (Comunicado Técnico, 51)

VAZ, C.M.P.; MANIERI, J .M.; MARIA, I.C. \& TULLER, M. Modeling and correction of soil penetration resistance for varying soil water content. Geoderma, 166:92-101, 2011. 